\title{
Jurist-Diction
}

Volume 2 No. 5, September 2019

Histori artikel: Submit 1 Agustus 2019; Diterima 8 Agustus 2019; Diterbitkan online 1 September 2019.

\section{Sengketa Verifikasi Partai Politik pada Badan Pengawas Pemilihan Umum}

\author{
Puspita Gita Devi \\ puspitagd97@gmail.com \\ Universitas Airlangga
}

\begin{abstract}
General election is the real form of democracy conducted by state as a manifestation of people sovereignity. In order to held a democratic election there should be an independent supervision. The establishment of supervisory instituion intended strengthen the pillar of democracy. Bawaslu is one of the institution which involved in the general election. Its objective is to supervise the general election in Unitary State of Republic of Indonesia (NKRI) and gauarantee a democratic practice of general election. One of its authority in supervising the election process is settling the election dispute. Election dispute is a dispute between the participants in the general election and dispute between the participants and the institution. Bawaslu's decision in settling the dispute is bound to the dispute parties, as stipulated in Article 469 paragraph (1) on General Election. It stated that any decision of Bawaslu regarding the settlement of the dispute is final and bind the dispute parties, unless the decision regarding the verification of the political parties as the participants of the general election. This research use juridical-normative approach. This research is focusing on the bawaslu's decision regarding the dispute of verification of political parties and its standing and statusof its final and binding decision.
\end{abstract}

Keywords: General Election's Dispute; Verification of Political Parties; Supervisory Institution of General Election.

\begin{abstract}
Abstrak
Pemilihan umum pada hakikatnya merupakan wujud nyata demokrasi yang dilaksanakan oleh negara sebagai wujud kedaulatan rakyat, untuk mewujudkan pemilihan umum yang demokratis harus adanya lembaga pengawasan yang independen dan mandiri. Lembaga pengawasan pemilu dibentuk untuk memperkuat pilar demokrasi. Bawaslu merupakan salah satu lembaga penyelenggara pemilihan umum yang berwenang mengawasi penyelenggaraan pemilihan umum di seluruh qilayah Negara Kesatuan Republik Indonesia. Sehingga adanya Bawaslu untuk mengawal dan mewujudkan serta menjamin bahwa pelaksanaan pemilihan berjalan secara demokratis. Salah satu kewenangan yang dimiliki oleh Bawaslu dalam mengawal serta mengawasi pemilihan umum yaitu menyelesaikan sengketa pemilihan, yang dimaksud dengan sengketa pemilihan yaitu sengketa antar peserta pemilu dan sengeta antara peserta dengan penyelenggara pemilu. Dalam menyelesaikan sengketa pemilu, keputusan Bawaslu bersifat mengikat, menurut Pasal 469 ayat (1) tentang pemilihan umum menyebutkan bahwa keputusan Bawaslu mengenai sengketa proses pemilu bersifat final dan mengikat, kecuali putusan terhadap sengketa proses pemilu yang berkaitan dengan verifikasi partai politik peserta pemilu. Penelitian ini menggunakan pendekatan yuridis normatif penyusunan skripsi ini difokuskan pada keputusan badan pengawas pemilihan umum dalam menyelesaikan sengketa verifikasi partai politik dan terkait kedudukan serta keputusan final dan mengikat dari badan pengawas pemilihan umum.
\end{abstract}

Kata Kunci: Sengketa Pemilihan Umum; Verifikasi Partai Politik; Badan Pengawas Pemilihan umum. 


\section{Pendahuluan}

Pemilihan umum merupakan sarana bagi masyarakat untuk turut aktif dalam proses politik yang ada agar terciptanya prinsip-prinsip dasar negara yang demokratis. Oleh karena itu untuk melaksanakan proses kedaulatan rakyat dengan memberikan mandat kepada calon-calon pemimpin untuk mengisi jabatan wakilwakil rakyat dilakukan keterlibatan masyarakat secara langsung yaitu melalui pemilihan umum.

Sebagai bentuk realisasi kedaulatan rakyat Negara Kesatuan Republik Indonesia maka penyelenggara pemilihan umum harus sesuai dengan tujuannya. Dengan hal ini pemerintah harus mempunyai mekanisme pengaturan yang jelas dan tepat agar pemilu berjalan sesuai prinsip demokrasi. Partai politik juga merupakan sarana dalam mewujudkan negara yang demokratis, karena partai politik dapat menjadi penghubung secara langsung antara negara dan rakyat. ${ }^{1}$

Pemilihan Umum yang demokratis mengharuskan adanya pengawasan dari lembaga - lembaga yang telah diatur oleh undang - undang yang memang memiliki wewenang untuk pengawasan pemilihan umum tersebut. Pengawasan pemilihan umum sendiri ini diwujudkan agar pemilihan umum memiliki kreadibilitas dan integritas yang berasaskan asasnya yaitu luberjurdil (Langsung, Umum, Bebas, Rahasia, Jujur, dan Adil) selain itu pentingnya pengawasan pemilu juga berkaitan untuk tetap mewujudkan terselenggaranya pemilu yang taat prosedur dan tahapan pencalonan yang berjalan secara demokratis serta guna mewujudkan kedaulatan rakyat sebagaimana diatur dalam UUD NRI 1945. Maka dari itu pemilihan umum perlu pengawasan agar berjalan sesuai dengan tujuan dan aturan yang telah ditetapkan.

Menurut UUD NRI 1945 kedaulatan rakyat dilakukan oleh berbagi lembaga negara sesuai dengan bidang dan tugasnya masing-masing. ${ }^{2}$ Dalam hal ini dengan terbaginya tugas masing-masing lembaga negara secara jelas dan terperinci dapat menghindari tumpang tindih dan tidak ada intervensi kewenangan antar lembaga negara ( Separation of Power ). Penyelenggara pemilihan umum adalah lembaga

\footnotetext{
${ }^{1}$ Jimly Asshiddiqie, Menegakkan Etika Penyelenggara Pemilu (2013).[11].

2 Ramlan Surbakti, Perubahan UUD 1945 Dalam Prespektif Politik (AIPI 2002)[435-439].
} 
yang menyelenggarakan pemilihan umum yang terdiri atas Komisi Pemilihan Umum (KPU), Badan Pengawas Pemilu (Bawaslu), Dewan Kehormatan Penyelenggara Pemilihan umum (DKPP) sebagai satu kesatuan fungsi Penyelenggaraan Pemilihan umum, hal ini dijelaskan dalam Pasal 1 Ketentuan Umum Undang - Undang Nomor 7 Tahun 2017 tentang Pemilu.

Keberadaan KPU dan Bawaslu sebagai kesatuan fungsi penyelenggaraan pemilihan umum, yaitu keberhasilan dalam pemilu tidak dapat ditentukan oleh kinerja KPU saja dalam melaksanakan semua tahap pemilu tetapi juga ada peran penting oleh Bawaslu. Bagian pengawasan penyelenggaraan pemilu dilakukan langsung oleh Bawaslu dengan secara langsung bertugas untuk mengawasi penyelenggara Pemilu di seluruh wilayah Negara Kesatuan Republik Indonesia dan Bawaslu bersifat tetap. Dalam tugas pengawasan penyelenggaraan pemilu Bawaslu mengawasi dari tahap persiapan penyelenggaraan hingga tahap pelaksanaan. Setelah adanya UU Nomor 22 Tahun 2007 Tentang Penyelenggara Pemilihan Umum, keberadaan Bawaslu dan KPU sudah tidak berjenjang namun sejajar, hal ini dilakukan untuk mewujudkan pengawasan yang efektif, karena lembaga pengawasan yaitu Bawaslu harus dipisahkan dari lembaga yang diawasinya. Tidak hanya KPU dan Bawaslu yang mempunyai peran penting dalam penyelenggaraan pemilihan umum namun kinerja KPU dan Bawaslu juga harus tetap diawasi agar tetap memenuhi kode etik. Dalam hal ini yang bertugas mengawasi kode etik penyelenggara pemilu adalah Dewan Kehormatan Penyelenggara Pemilihan Umum yang selanjutnya disebut DKPP. ${ }^{3}$

Pengaturan mengenai Bawaslu dalam Undang - Undang Nomor 7 Tahun 2017 tentang Pemilihan Umum, mengalami beberapa perubahan jika dibandingkan dengan undang - undang sebelumnya. Menurut undang - undang ini yaitu Bawaslu setidaknya memiliki 5 tugas yaitu mengawasi pelaksanaan tahapan pemilihan umum, melakukan penindakan hukum administrasi, etik, dan pidana pemilihan umum yang ketiga melakukan pencegahan, yang keempat mengawasi putusan yang berkenaan dengan penyelenggaraan pemilihan umum dalam menjalankan tugas

${ }^{3}$ Ramlan Surbakti, Studi Tentang Desain Kelembagaan Pemilu Yang Efektif (2015). [43]. 
pengawasan penyelenggaraan pemilu, dan Bawaslu diberikan kewenangan dalam penyelesaian sengketa pemilu.

Tugas Bawaslu dalam Undang-Undang Nomor 7 Tahun 2017 tentang Pemilihan Umum diatur secara rinci pada Pasal 93. Dalam undang - undang ini tugas Bawaslu tidak hanya sekedar mengawasi namun bisa juga melakukan penindakan terhadap pelanggaran pemilu. Dengan semakin bertambah banyaknya tugas Bawaslu pada undang - undang ini, Bawaslu juga bertugas mengawasi putusan yang dikeluarkan oleh lembaga yang berkaitan dengan pemilu. Kewenangan baru yang dimiliki oleh Bawaslu yaitu dalam hal penanganan sengketa pemilu, diatur dalam Undang-Undang Nomor 7 Tahun 2017 Bawaslu tidak hanya sebatas menerima dan memeriksa sengketa pemilu namun Bawaslu juga berwenang melakukan mediasi, melakukan sidang ajudikasi.

Sengketa yang timbul salah satunya adalah dalam proses tahap verifikasi partai politik. Dalam tahap ini KPU menentukan partai politik tersebut dinyatakan lolos atau tidak untuk menjadi peserta pemilu, biasanya hasil dari verifikasi KPU ini yang akan menimbulkan sengketa. Berkaitan masalah sengketa KPU hanya berperan sebagai pelaksana putusan Bawaslu mengenai sanksi atas pelanggaran administratif dan sengketa proses pemilu. Bawaslu sendiri sebagai bentuk quasi pengadilan atau semi pengadilan dalam pemilu. ${ }^{4}$ Bawaslu yang bertugas memproses sengketa sampai memutuskan penyelesaian sengketa pemilu dengan cara melakukan upaya administratif sebelum sengketa dibawa ke Pengadilan Tata Usaha Negara.

Dalam pasal 469 ayat (1) ditegaskan bahwa:

"Putusan Bawaslu mengenai sengketa proses pemilu merupakan putusan yang bersifat final dan mengikat, kecuali putusan terhadap sengketa proses pemilu yang berkaitan dengan:

a. Verifikasi partai politik peserta pemilu

b. Penetapan daftar calon tetap anggota DPR, DPD, DPRD provinsi, dan DPRD kabupaten/kota; dan

c. Penetapan pasangan calon".

${ }^{4}$ Komisi Yudisial Republik Indonesia, Putih Hitam Pengadilan Khusus (2013).[3]. 
Dalam hal ini dapat muncul pertanyaan, mengapa putusan Bawaslu ini dikecualikan dalam hal sengketa proses pemilu. Beberapa hal mengenai kewenangan baru Bawaslu yang harus diperhatikan yaitu, Bawaslu menjalankan fungsi-fungsi peradilan yaitu untuk memutuskan sengketa yang timbul, tetapi disaat yang bersamaan Bawaslu juga menjalankan fungsi pengawasan yang merupakan fungsi Bawaslu itu sendiri. Dalam hal ini dapat menimbulkan konflik yaitu ketika menjalankan fungsi pengawasan akan dapat mempengaruhi di dalam suatu putusan yang dikeluarkan oleh Bawaslu. ${ }^{5}$

Berdasarkan uraian diatas, maka rumusan masalah yang akan dikaji dalam penulisan ini pertama adalah, kedudukan dan sifat putusan Bawaslu dalam menyelesaikan sengkea verifikasi partai politik dan implikasi yuridis Bawaslu dalam hal sengketa verifikasi partai politik erhadap KPU dan penerapan calon partai politik peserta pemilu. Penelitian ini merupakan penelitian hukum dengan metodologi pendekatan peraturan perundangundangan, dan pendekatan kasus.

\section{Kedudukan dan Sifat Putusan Bawaslu dalam Menyelesaikan Sengketa Verifikasi Partai Politik}

Lahir sebagai penyelenggara pemilihan umum yang bertujuan untuk mewujudkan kedaulatan rakyat agar berjalan dengan jujur dan adil sebagaimana dijelaskan dalam Pasal 1 Angka 17 Undang - Undang Nomor 7 Tahun 2017 disebutkan bahwa:

"Badan Pengawas Pemilu yang selanjutnya disebut Bawaslu adalah lembaga Penyelenggara Pemilu yang mengawasi Penyelenggaraan Pemilu di seluruh wilayah Negara Kesatuan Republik Indonesia."

Dalam pelaksanaannya lembaga pengawas pemilu dapat berfungsi secara efektif jika :

\footnotetext{
5 Didik Supriyanto, "Menyoal Bawaslu, Penampilan Baru, Wewenang Baru, Persoalan Baru" (2018) https://nasional.kompas.com/read/2017/11/08/14273471/menyoal-bawaslu-penampilan-baru-wewenang-baru-persoalan-baru , Diunduh 1 Oktober 2018.
} 
a. Posisi lembaga itu independen

b. Memiliki kewenangan yang cukup;

c. Memiliki personal yang cukup;

d. Memiliki kesempatan yang cukup. ${ }^{6}$

Pembentukan lembaga-lembaga negara independen harus memiliki landasan berpijak yang kuat dan paradigma yang jelas agar keberadaan lembaga tersebut dapat membawa manfaat bagi kepentingan publik pada umumnya serta bagi penataan sistem ketatanegaraan pada khususnya. Bawaslu sebagai lembaga pengawas yang bersifat independen untuk menyelenggarakan pemilu sesuai dengan asasnya yaitu langsung, umum, bebas, rahasia, jujur, dan adil, dan memastikan serta menjamin netralitas dan ketidakberpihakan penyelenggara pemilu. Penyelenggara pemilu tidak boleh dikendalikan oleh partai politik sebagai peserta pemilu, karena jika hal tersebut terjadi maka free and fair election tidak akan bisa terwujud. ${ }^{7}$

Dalam mewujudkan pengawasan pemilu berjalan secara efektif perlu memperhatikan kewenangan yang dimiliki oleh lembaga pengawas pemilu agar tidak cenderung disalahgunakan (abuse of power) karena menurut Undang-Undang Nomor 7 Tahun 2017 tentang Pemilihan Umum Bawaslu memiliki kewenangan besar, tidak hanya sebagai pengawas sekaligus menjadi eksekutor hakim pemutus perkara.

Dalam menyelesaikan sengketa pemilu dengan Bawaslu menurut Undang -Undang Nomor 7 Tahun 2017 dapat diselesaikan dengan mempertemukan para pihak yang bersengketa untuk mencapai kesepakatan melalui musyawarah mufakat. Jika dalam hal musyawarah tidak tercapai kesepakatan antara para pihak, Bawaslu menyelesaikan sengketa melalui ajudikasi. Keputusan Bawaslu mengenai penyelesaian sengketa merupakan putusan yang bersifat final dan mengikat.

Bedasarkan Undang - Undang Nomor 7 Tahun 2017 tersebut, secara umum proses penyelesaian sengketa pemilu menempatkan Bawaslu sebagai penengah antara para pihak yang bersengketa, baik antar peserta pemilu atau peserta pemilu dengan KPU sebagai penyelenggara pemilu sebagai penengah Bawaslu diberikan kewenangan untuk mengeluarkan keputusan penyelesaian sengketa. Hal itu diatur

\footnotetext{
${ }^{6}$ Ni'matul Huda dan M. Imam Nasef, Op.Cit.[87].

7 ibid.[108].
} 
dalam Pasal 469 Undang - Undang Nomor 7 Tahun 2017 tentang Pemilihan Umum yaitu putusan Bawaslu mengenai penyelesaian sengketa proses pemilu bersifat final dan mengikat, kecuali putusan terhadap sengketa proses Pemilu yang berkaitan dengan verifikasi partai politik peserta pemilu,penetapan daftar calon tetap anggota DPR, DPD, DPRD provinsi, dan DPRD kabupaten/kota dan penetapan pasangan calon.

\section{Implikasi Yuridis Keputusan Bawaslu dalam Sengketa Verifikasi Partai Politik Terhadap KPU dan Calon Partai Politik Peserta Pemilu.}

Sengketa proses Pemilu adalah sengketa yang terjadi antara peserta Pemilu dan sengketa peserta Pemilu dengan penyelenggara Pemilu sebagai akibat dikeluarkannya keputusan KPU, keputusan KPU Provinsi, dan keputusan KPU Kabupaten/Kota. Melihat dari ketentuan ini secara eksplisit jenis sengketa dapat dibagi menjadi dua, yaitu sengketa antar peserta Pemilu dan sengketa peserta Pemilu dengan penyelenggara Pemilu sebagai akibat dikeluarkannya kepuusan KPU. Bawaslu dalam menyelesaikan sengketa tersebut melakukan tahapan penyelesaian sengketa sebagaimana diatur dalam Pasal 468 ayat (3) dan (4) UU Pemilu yang menyatakan:

Pasal 468 ayat (3). Bawaslu melakukan penyelesaian sengketa proses Pemilu melalui tahapan:

a) Menerima dan mengkaji permohonan penyelesaian sengketa proses pemilu

b) Mempertemukan pihak yang bersengketa untuk mencapai kesepakatan melalui mediasi atau musyawarah mufakat.

Bedasarkan aturan tersebut, secara umum Bawaslu sebagai penengah antara pihak - pihak yang bersengketa. Sebagai penengah Bawaslu mempunyai kewenangan untuk mengeluarkan keputusan penyelesaian sengketa. Hal ini dapat dilihat dalam Pasal 469 ayat 1 UU Pemilu yang menjelaskan bahwa penyelesaian sengketa proses pemilu bersifat final dan mengikat, kecuali putusan terhadap sengketa proses Pemilu yang berkaitan dengan verifikasi partai politik peserta 
pemilu,penetapan daftar calon tetap anggota DPR, DPD, DPRD provinsi, dan DPRD kabupaten/kota dan penetapan pasangan calon tetap anggota DPR, DPD, DPRD provinsi, dan DPRD kabupaten/kota serta penetapan pasangan calon.

Keputusan Bawaslu yang tidak bersifat final dan mengikat merupakan keputusan dalam menyelesaikan sengketa antara peserta Pemilu dengan penyelenggara Pemilu akibat dikeluarkannya keputusan KPU terkait verifikasi artai politik peserta pemilu dan daftar calon tetap anggota DPR, DPD, DPRD provinsi, kabupaten/kota. Sedangkan keputusan yang bersifat final dan mengikat adalah keputusan penyelesaian sengketa selain untuk dua jenis sengketa tersebut. Khusus terkait penyelesaian sengketa verifikasi partai politik peserta pemilu dan daftar calon tetap anggota DPR, DPD, DPRD provinsi dan kabupaten/kota penyelesaian sengketa terkait keputusan KPU tersebut yang dilakukan oleh Bawaslu tidak diterima oleh para pihak dapat mengajukan upaya hukum kepada Pengadilan Tata Usaha Negara. Hal ini sejalan dengan Pasal 469 ayat (1) yang secara langsung mengatur keputusan Bawaslu yang tidak bersifat final, oleh karena itu terbuka ruang untuk dilakukan upaya berikutnya seelah Bawaslu mengeluarkan keputusan penyelesaian sengketa. Upaya tersebut dapat dilakukan di Pengadilan Tinggi Tata Usaha Negara.

Keputusan sengketa oleh Bawaslu yang bersumber pada putusan KPU tentang penetapan partai politik setelah adanya verifikasi partai politik sebagai peserta pemilu masih bisa digugat ke PTUN dengan alasan:

a. Materi keputusan Bawaslu tersebut terkait langsung dengan proses dan hasil pemilu, sehingga status kepersetaan partai politik dan pencalonan harus berdasarkan keputusan penyelenggara pemilu yang mempunyai wewenang penuh menyelenggarakan pemilu.

b. Koreksi terhadap dua keputusan itu yaitu KPU dan Bawaslu hanya bisa dilakukan oleh lembaga peradilan, sementara Bawaslu dan jajarannya dalam desain kelembagaan pemilu bukan merupakan lembaga peradilan. ${ }^{8}$

${ }^{8}$ Didik Supriyanto, Op. Cit.[101]. 
Dalam prespektif electoral justice system penyelesaian sengketa yang baik harus memenuhi unsur - unsur adanya hak untuk mendapatkan penyelesaian sengketa pemilu; adanya perangkat standar dan prosedur pemilu yang jelas; adanya badan pemutus perkara yang memiliki pengetahuan dan tidak berpihak; adanya sistem peradilan yang memperlancar tercapainya keputusan; adanya pengaturan yang jelas tentang beban pembuktian dan standar pengajuan bukti yang ditetapkan dengan jelas; adanya sistem penyelesaian yang efektif dan bermakna dan adanya pendidikan pemangku kepentingan yang efektif. ${ }^{9}$

Dalam konteks pelaksanaan pemilu sering terjadi ketidakpuasan dengan apa yang terjadi dalam proses penyelenggaran pemilu, sedangkan siapa yang berwenang menangani sengketa pemilihan umum yaitu sebagaimana pada Pasal 468 ayat (1) Undang -Undang Nomor 7 Tahun 2017 tentang Pemilihan Umum, yang menyatakan Bawaslu berwenang menyelesaikan sengketa proses pemilu. Mengenai mekanisme tentang penyelesaian sengketa pemilu diatur lebih lanjut pada Pasal 468 yaitu:

(3) Bawaslu, bawaslu Provinsi, Bawaslu Kabupaten/Kota melakukan penyelesaian sengketa proses pemilu melalui tahapan:

a. Menerima dan mengkaji permohonan penyelesaian sengketa proses pemilu; dan

b. Mempertemukan pihak yang bersengketa untuk mencapai kesepakatan melalui mediasi atau musyawarah mufakat.

(4) Dalam hal tidak tercapai kesepakatan antara para pihak yang bersengketa sebagaimana dimaksud pada ayat (3) huruf b, Bawaslu menyelesaikan sengketa proses pemilu melalui ajudikasi.

Dapat dimaknai bahwa dalam menyelesaikan sengketa pemilihan umum Bawaslu mempunyai dua mekanisme penyelesaian yaitu melalui musyawarah dan apabila tidak mencapai mufakat maka menyelesaikan sengketa dengan cara ajudikasi. Dalam menyelesaikan sengketa proses pemilu melalui kedua mekanisme tersebut diatur dalam Pasal 469 Undang - Undang Nomor 7 Tahun 2017 mengenai keputusan Bawaslu dalam menyelesaikan sengketa bersifat final dan mengikat

${ }^{9}$ Bambang Eka Cahyono, Penyelesaian Sengketa Pilkada Serentak Tahun 2015 Dalam Prespektif Electoral Justice System (2015).[1]. 
kecuali sengketa yang dikecualikan, sehingga keputusan Bawaslu adalah terakhir dan tidak ada upaya hukum lagi kecuali yang berkaitan dengan keputusan mengenai sengketa verifikasi partai politik, penetapan daftar calon tetap, dan penetapan pasangan calon maka putusan final dan mengikat.

Terbuka ruang bagi KPU untuk mengambil sikap dan keputusan yang berbeda jika tidak menerima keputusan Bawaslu. Pengecualian norma hukum yang tercantum dalam Pasal 469 ayat (1) Undang - Undang Nomor 7 Tahun 2017 tersebut tidak boleh disimpangi dengan keputusan Bawaslu. Dapat berlaku asas hukum Lex Superiori Derogat Legi Inferiori, yaitu peraturan yang lebih tinggi tidak dapat dihapus oleh peraturan yang lebih rendah kedudukannya.

Dengan hal ini KPU boleh mengabaikan keputusan Bawaslu dan masih bisa melakukan upaya hukum berikutnya yang dapat ditempuh oleh KPU dan partai yang bersengketa. Dengan demikian partai yang bersengketa dengan KPU terkait verifikasi partai politik peserta pemilu tidak secara langsung dapat menjadi peserta pemilu pasca putusan Bawaslu yang menolak keputusan KPU terkait verifikasi partai politik peserta pemilu. Sama halnya dengan upaya hukum yang dapat dilakukan oleh partai politik ketika tidak puas terhadap putusan KPU, dapat mengajukan sengketa ke Bawaslu. Apabila setelah Bawaslu mengeluarkan keputusan dan para pihak masih merasa tidak puas, maka partai politik dapat menempuh upaya hukum banding ke PTUN. Keputusan tersebut merupakan bagian dari keputusan yang dikeluarkan oleh suatu lembaga penyelenggara pemilihan umum dengan wewenang yang diberikan oleh negara, karena adanya badan pengawas pemilihan umum yang memiliki kewenangan untuk memeriksa dan mengadili sengketa pemilihan tersebut karena pada hakikatnya badan pengawas pemilihan umum tersebut merupakan satu instrumen penegakan hukum yang mampu dan paham dalam mengawasi pelanggaran yang ada. Kewenangan yang dimiliki badan pengawas pemilu tersebut untuk mengakhiri suatu sengketa, termasuk sengketa verifikasi partai politik dengan sebuah keputusan yang dikeluarkan maka harus ditaati oleh semua pihak yang bersangkutan termasuk KPU. 


\section{Kesimpulan}

Kewenangan penyelesaian sengketa yang dimiliki oleh Bawaslu berdasarkan UU Pemilu dalam mengeluarkan putusan bersifat final and binding. Dari aspek kekuatan berlakunya putusan, dapat dibagi menjadi dua bagian, yakni putusan yang belum memiliki kekuatan hukum tetap, dan putusan yang telah memiliki kekuatan hukum tetap (inkracht van gewijsde). Putusan yang belum memiliki kekuatan hukum tetap, merupakan putusan yang masih terbuka jalan untuk dilakukan upaya hukum selanjutnya. Sedangkan putusan inkracht merupakan putusan yang tidak dapat lagi dilakukan upaya hukum biasa untuk melawannya (banding dan kasasi). Dengan demikian, putusan yang bersifat final and binding merupakan putusan akhir yang inkracht dan tidak dapat dilakukan upaya hukum lagi. Dalam putusan Bawaslu terhadap sengketa proses pemilihan umum bersifat final dan mengikat kecuali putusan terhadap sengketa verifikasi partai politik peserta pemilu, penetapan daftar calon tetap anggota DPR, DPD, DPRD provinsi, dan DPRD kabupaten/kota dan penetapan pasangan calon. Berdasarkan UU Pemilu, fungsi adjudikasi yang dimiliki Bawaslu dapat dilaksanakan untuk menerima, memeriksa, mempertimbangkan, dan memutus pelanggaran administrasi Pemilu, dan sengketa proses Pemilu. Jika Bawaslu masih menguatkan penetapan dari keputusan KPU dengan menolak permohonan dari pemohon (partai politik peserta pemilu) maka partai politik yang bersangkutan dapat mengajukan banding ke Pengadilan Tata Usaha Negara (PTUN).

\section{Daftar Bacaan}

\section{Buku}

Bambang Eka Cahyono, Penyelesaian Sengketa Pilkada Serentak Tahun 2015 Dalam Prespektif Electoral Justice System (Fisipol Universitas Muhammadiyah 2015).

Jimly Asshiddiqie, Menegakkan Etika Penyelenggara Pemilu (Rajawali Pers 2013).

Komisi Yudisial Republik Indonesia, Putih Hitam Pengadilan Khusus, (Pusat Analisis dan Layanan Informasi Sekertariat Jendral Komisi Yudisial 2013).

Ni'matul Huda dan M. Imam Nasef, Penataan Demokrasi dan Pemilu di Indonesia 
Pasca Reformasi (Prenada Media Group 2017).

Ramlan Surbakti, Perubahan UUD 1945 Dalam Prespektif Politik(AIPI 2002).

Ramlan Surbakti, Studi Tentang Desain Kelembagaan Pemilu Yang Efektif (Kemitraan bagi pembaruan Tata Pemerintahan 2015).

Ni'matul Huda dan M. Imam Nasef, Penataan Demokrasi dan Pemilu di Indonesia Pasca Reformasi ( Prenada Media Group 2017).

\section{Jurnal}

Didik Supriyanto, 'Menyoal Bawaslu, Penampilan Baru, Wewenang Baru, Persoalan Baru’ (2018).

\section{Perundang-undangan}

Undang-Undang Dasar Negara Republik Indonesia Tahun 1945.

Undang - Undang Nomor 7 Tahun 2017 tentang Pemilihan Umum (Lembaran Negara Republik Indonesia Tahun 2017 Nomor 182).

Peraturan Komisi Pemilihan Umum Nomor 6 Tahun 2018 tentang Pendaftaran, Verifikasi dan Penetapan Partai Politik Peserta Pemilihan Umum Anggota Dewan Perwakilan Rakyat dan Dewan Perwakilan Rakyat Daerah.

Peraturan Komisi Pemilihan Umum Nomor 5 Tahun 2018 tentang Tahapan, Progam dan Jadwal Penyelenggaraan Pemilihan Umum Tahun 2019.

Putusan Mahkamah Konstitusi Nomor 11/PUU-VIII/2010 Tahun 2010 tentang Pengujian Undang - undang Nomor 22 Tahun 2007 Tentang Penyelenggara Pemilihan Umum.

Putusan Mahkamah Agung Republik Indonesia Nomor 56/G/SPPU/2018/PTUN-JKT.

Surat Keputusan (SK) Pemilu Nomor 58/PL.01.1.-Kpt/03/KPU/II/2018 tentang Penetapan Partai Politik Peserta Pemilihan Umum Anggota Dewan Perwakilan Rakyat, Dewan Perwakilan Rakyat Provinsi, dan Dewan Perwakilan Rakyat Daerah Kabupaten/ Kota Tahun 2019.

Keputusan Bawaslu Nomor 012/PS-REG2/BAWASLU/II/2018 Tentang Keputusan Bawaslu tentang Menolak Keberatan PKPI Terhadap Keputusan KPU.

Putusan BAWASLU No. 008/PS.REG/BAWASLU/II/2018.

HOW TO CITE: Puspita Gita Devi, ‘Sengketa Verifikasi Partai Politik pada Badan Pengawas Pemilihan Umum' (2019) Vol. 2 No. 5 JuristDiction. 